\title{
APLIKASI PEMBELAJARAN IQRA BERBASIS ANDROID MENGGUNAKAN SPEECH RECOGNITION DAN AUGMENTED REALITY
}

\author{
Azli Ayu Anggraini' ${ }^{1)}$, Maksum Ro'is Adin Saf ${ }^{2)}$ \\ ${ }^{1}$ Teknik Informatika, Politeknik Caltex Riau \\ email: azli16ti@mahasiswa.pcr.ac.id \\ ${ }^{2}$ Teknik Informatika, Politeknik Caltex Riau \\ email:maksum@pcr.ac.id
}

\begin{abstract}
At the TPA level, children have been introduced to read iqra. The method used is the iqra book. The results of pre-research conducted on parents and teachers are children are still difficult to be directed, tend to play, quickly get bored, and sometimes have to be a little forced to read iqra. This iqra learning application utilizes Speech recognition and Augmented reality technology as an alternative media to increase children's interest in reading iqra. In Speech recognition users use voice input to recognize iqra readings, while Augmented reality displays $3 D$ forms of iqra readings to make them look real. Based on the results of the functionality testing conducted, the application built has run in accordance with its function. In the statistical tests that have been carried out it can be concluded that the results after using the application are greater than before using the application, where the application used has been significantly successful, because parents feel this iqra learning application can be used as an alternative media to help it in teaching iqra to children .
\end{abstract}

Keywords: Iqra learning, Augmented Reality, Speech Recognition.

\section{Abstrak}

Pada tingkat TPA, anak-anak sudah diperkenalkan membaca iqra. Metode yang digunakan adalah buku iqra. Hasil pra riset yang lakukan terhadap orang tua dan guru adalah anak-anak masih susah diarahkan, cenderung bermain, cepat merasa bosan, dan terkadang harus sedikit dipaksa untuk membaca iqra. Aplikasi pembelajaran iqra ini memanfaatkan teknologi Speech recognition dan Augmented reality sebagai media alternatif untuk menambah minat anak-anak dalam membaca iqra. Pada Speech recognition user menggunakan inputan suara untuk mengenal bacaan iqra sedangkan Augmented reality menampilkan bentuk 3D bacaan iqra agar terlihat tampak nyata. Berdasarkan hasil pengujian fungsionalitas yang dilakukan, aplikasi yang dibangun telah berjalan sesuai dengan fungsinya. Pada uji statistik yang telah dilakukan dapat disimpulkan bahwa hasil sesudah menggunakan aplikasi lebih besar dibanding sebelum menggunakan aplikasi, dimana aplikasi yang digunakan telah berhasil secara signifikan, karena orang tua merasa aplikasi pembelajaran iqra ini dapat dijadikan media alternatif untuk membantunya dalam mengajarkan iqra kepada anak-anak.

Keywords: Pembelajaran Iqra, Augmented Reality, Speech Recognition.

\section{PENDAHULUAN}

Buku Iqra merupakan buku ajar membaca Al-Qur'an yang sangat populer di Indonesia. Buku karya KH. As'ad Humam ini banyak digunakan di Taman pendidikan Al-Qur'an. Buku ini diperuntukkan bagi anak-anak untuk mencapai kemahiran membaca Al-Qur'an. Buku Iqra terdiri dari 6 jilid dan tingkat kesulitannya pun berbeda-beda[1].

Berdasarkan hasil pra riset yang dilakukan terhadap orang tua dan guru di tiga MDTA yaitu MDTA ASH-SIDDIQ, MDTA ALIHSAN, dan MDTA AL-BAYAN mengatakan bahwa anak-anak sudah diajarkan membaca iqra, anak-anak akan diperkenalkan terlebih dahulu huruf hijaiyah, makhrojul huruf, selanjutnya orang tua atau guru akan membacanya terlebih dahulu kemudian diikuti oleh anak-anak. Permasalahan yang dialami adalah anak-anak masih susah diarahkan, cenderung bermain, cepat merasa bosan, dan terkadang harus sedikit dipaksa. 
Merujuk dari permasalahan yang disampaikan di atas maka memerlukan media alternatif yaitu aplikasi pembelajaran berbasis android. Berdasarkan hasil pra riset menyatakan bahwa anak-anak lebih cepat menangkap pelajaran dalam bentuk objek visual, maka dibangun sebuah aplikasi pembelajaran berbasis android yang dapat membantu guru dan orang tua untuk mengajarkan anak-anak belajar dan membaca iqra. Aplikasi pembelajaran adalah media yang digunakan dalam pembelajaran, yaitu meliputi alat bantu guru dalam mengajar serta sarana pembawa pesan dari sumber belajar ke penerima pesan belajar (siswa)[2]. Aplikasi ini dibangun pada platform android dan akan dikembangkan menggunakan teknologi Augmented Reality dan Speech Recognition. Augmented Reality adalah sebuah virtual yang dapat kita munculkan ke dalam dunia nyata dengan perantara kamera[3]. Penggunakan Augmented Reality sangat berguna untuk media pembelajaran yang interaktif dan nyata serta secara langsung oleh peserta didik. Selain itu media pembelajaran menggunakan Augmented Reality dapat meningkatkan minat peserta didik dalam belajar, karena sifat Augmented Reality yang menggabungkan dunia maya yang dapat meningkatkan imajinasi peserta didik dengan dunia nyata secara langsung[4]. Augmented Reality bersifat interaktif yang membuat peserta didik untuk melihat keadaan secara nyata dan langsung serta dapat mengimajinasikan hasil proses pembelajaran yang diberikan pendidik kepada peserta didik. Speech recognition merupakan kemampuan suatu perangkat elektronik untuk untuk mengenali kata-kata yang terucap [5]. Speech recognition juga dapat di artikan sebagai proses menangkap kata yang diucapkan melalui mikropon atau telepon dan mengubahnya ke dalam kata-kata yang tersimpan secara digital[6].

\section{METODE PENELITIAN}

\footnotetext{
Metodologi yang digunakan pada penelitian ini adalah:

A. Studi Literatur, mencari referensi teori yang saling berkaitan dengan masalah yang ditemukan. Pengumpulan materi dilakukan seperi buku-buku dan jurnal mengenai Speech recognition dan Augmented reality.
}
B. Observasi,melakukan pengamatan terhadap aplikasi yang sejenis.
C. Perancangan sistem, dilakukan perancangan-perancangan secara rinci mengenai bagaimana sistem atau aplikasi berjalan.
D. Implementasi sistem, melakukan pembuatan aplikasi sesuai dengan perancangan sistem.
E. Melakukan Pengujian statistik, setelah merancang bangun aplikasi pembelajaran iqra berbasis Android ini, maka dilakukan tahapan pengujian, dilakukan kuisioner pra penelitian untuk mengetahui hasil pembelajaran dari aplikasi.
F. Analisis dan Evaluasi, dilakukan beberapa analisis dan evaluasi dari hasil yang telah didapat dan dilakukan pembuatan laporan.

\section{HASIL DAN PEMBAHASAN}

Implementasi dari hasil aplikasi pembelajaran iqra. Aplikasi pembelajaran iqra ini hanya terdapat iqra 1 sampai iqra 3 saja dan meliputi 2 menu utama yaitu pembelajaran dan latihan. Pada menu Pembelajaran menerapkan konsep Augmented reality yang memiliki marker, dimana ketika user menjalankan menu pembelajaran maka objek 3D dan suara pada marker akan tampil. Sedangkan pada menu latihan menerapkan konsep Speech recognition, dimana ketika user menjalan menu latihan, maka user diminta untuk menjawab pertanyaan dengan cara memberikan inputan suara.

\section{A. Hasil Perancangan}

Berikut adalah beberapa halaman yang terdapat pada aplikasi pembelajaran iqra. Pada sisi ini user berada pada bagian Augmented reality atau pada menu pembelajaran. Ketika kamera belakang ponsel terbuka, lalu user diminta untuk mengarahkan kamera ke arah marker. Setelah itu maka muncul seperti yang digambar. 


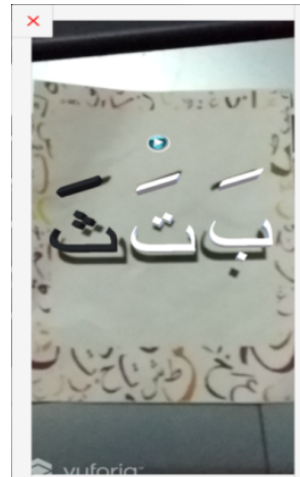

Gambar 1. Tampilan menu pembelajaran

Berikut contoh tampilan marker yang digunakan oleh peneliti

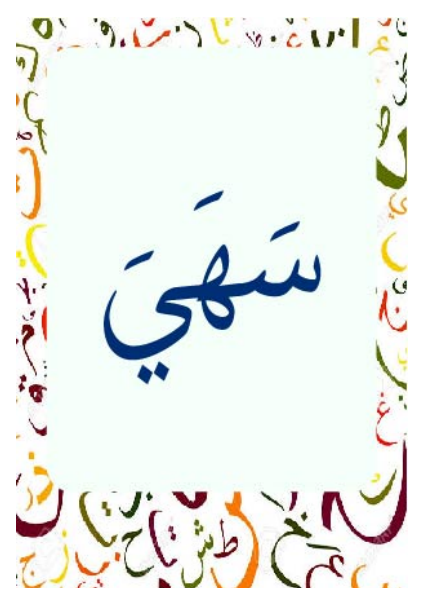

Gambar 2. Tampilan marker

Pada menu latihan, user akan diminta untuk menjawab pertanyaan dengan cara menginputkan suara.

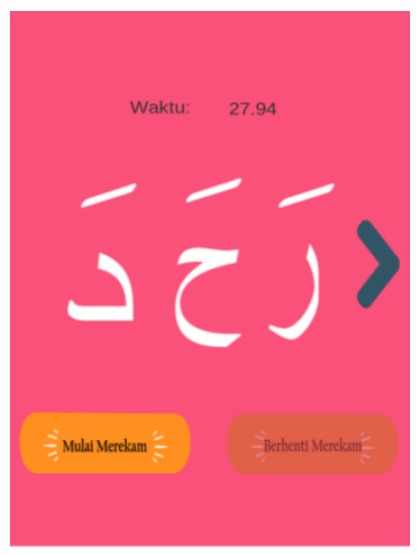

\section{Apakah bacaan diatas?}

Gambar 3. Tampilan menu latihan

B. Hasil Pengujian dan Analisis pada proyek akhir ini terdiri uji fungsi dengan black box test case. Pengujian dimaksudkan untuk mengetahui apakah fungsi-fungsi, masukan, dan keluaran dari perangkat lunak sesuai dengan spesifikasi yang dibutuhkan apakah sudah berjalan sesuai dengan seharusnya atau tidak[7]. Pengujian statistik untuk membandingkan dua jenis sampel yang berbeda disebut juga dengan uji perbedaan dua sampel dependen[8]. Pengujian ini dilakukan dengan membandingkan ratarata dari sampel sebelum menggunakan aplikasi dan sampel yang sudah menggunakan aplikasi. Rumus yang digunakan pada pengujian mean, yaitu :

$$
\mathrm{t}=\frac{\mathrm{d}}{\mathrm{Sd} \sqrt{\mathrm{n}}}
$$

Keterangan :

$$
\begin{aligned}
& \mathrm{D}: \text { rata-rata deviasi } \\
& \mathrm{Sd}: \text { Standar deviasi } \\
& \mathrm{n}: \text { Banyaknya sample } \\
& \mathrm{df}: \mathrm{n}-1 \text { (degree offreedom) }
\end{aligned}
$$

Adapun pembahasan proses pengujian adalah mengumpulkan data terhadap orangtua sebelum menggunakan aplikasi dan sesudah menggunakan aplikasi. Pengujin ini dilakukan dengan dua kelompok, kelompok pertama melakukan pengujian sebelum menggunakan aplikasi yaitu menggunakan buku iqra, kelompok kedua, melakukan pengujian menggunakan aplikasi pembelajaran iqra.

Adapun langkah-langkah dalam melakukan pengujian statistik[9]:

Kemudian dilakukan paired sample 1 test dan statistik deskriptif terkait data yang diolah normal atau tidak. Dimana proses pengujian statistik yang telah dilakukan adalah :

1. Penentuan rumusan hipotesis, baik $\mathrm{H}_{0}$ maupun $\mathrm{H}_{1} H 0: \mu 2 \leq \mu 1$ (Rata-rata) pengguna sesudah menggunakan aplikasi rata-rata nilai sebelum menggunakan aplikasi). $H 1: \mu 2>\mu 1$ (Rata-rata pengguna sesudah menggunakan aplikasi rata-rata nilai sebelum menggunakan aplikasi).

2. Penentuan tingkat signifikan $(\propto)$ yang diinginkan Pada penelitian ini tingkat signifikan $(\propto)$ yang digunakan adalah $5 \%$ atau 0,05 .

3. Penentuan nilai kritis berdasarkan $\propto$ di atas. Nilai kritis atau nilai kepercayaan yang digunakan adalah $95 \%$.

4. Penentuan statistik uji yang cocok 
untuk menguji hipotesis nol. Penelitian ini diuji terhadap 2 kelompok yaitu sebelum dan sesudah menggunakan aplikasi. Dalam kasus ini statistic uji yang cocok untuk menguji hipotesa nol adalah paired sample t-test (uji ratarata sampel berhubungan).

5. Perhitungan nilai statistic uji berdasarkan data yang diketahui dari populasi atau sampel.

untuk melakukan paired sample t-test maka ditentukan dahulu apakah data yang akan diolah tersebut normal atau tidak[10]. Maka dari ini, dilakukanlah Analisa statistik deskriptif seperti tabel dibawah :

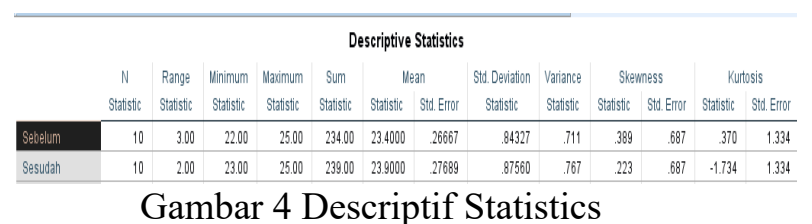

Berdasarkan data diatas, kemudian dilakukan perhitungan koefisien varians, rasio skewness, dan rasio kurtosis untuk mengetahui apakah data termasuk normal atau tidak.

a. Koefisien Varians

Untuk menentukan data yang didapat tersebut normal, maka nilai Koefisien Varians harus $<30 \%$. Berikut perhitungan KV:

$$
\begin{aligned}
\mathrm{KV}(\text { sebelum })= & (\mathrm{Sd} / \text { mean }) \times 100 \% \\
& =(0,84 / 23,4) \times 100 \% \\
& =3,58 \% \\
\mathrm{KV}(\text { sesudah })= & (\mathrm{Sd} / \text { mean }) \times 100 \% \\
= & (0,87 / 23,9) \times 100 \% \\
= & 3,64 \%
\end{aligned}
$$

Dari perhitungan diatas, disimpulkan bahwa nilai KV sebelum dan sesudah berada dibawah $30 \%$ dan data yang didapat termasuk normal.

b. Rasio Skewness

Dalam uji rasio skewness data disebut normal jika hasil uji rentang -2 sampai 2 . Berikut perhitungannya :

$$
\begin{aligned}
& \text { Skewness }(\text { sebelum })=\text { skewness } / \text { Std } \text {. } \\
& \text { error skewness } \\
& =0,38 / 0,68
\end{aligned}
$$

$$
=0.55
$$

Skewness (sesudah) = skewness / Std. error skewness

$$
\begin{aligned}
& =0,22 / 0,68 \\
& =0,32
\end{aligned}
$$

Dari perhitungan diatas, disimpulkan bahwa nilai rasio skewness sebelum dan sesudah berada didalam rentang -2 dan 2 sehingga data yang didapat termasuk normal.

c. Rasio Kurtosis

Dalam uji rasio kurtosis data disebut normal jika hasil uji rentang -2 sampai 2.

Berikut Perhitungannya

Kurtosis $($ sebelum $)=$ kurtosis $/$ Std. error kurtosis

$$
\begin{aligned}
& =0,37 / 1,33 \\
& =0,27
\end{aligned}
$$

Kutrosis $($ sesudah $)=$ kurtosis $/$ Std. error kurtosis

$$
\begin{aligned}
& =-1,73 / 1,33 \\
& =-1,30
\end{aligned}
$$

Dari perhitungan diatas disimpulkan bahwa nilai rasio kurtosis sebelum dan sesudah berada didalam rentang - 2 dan 2 sehingga data yang didapat termasuk normal.

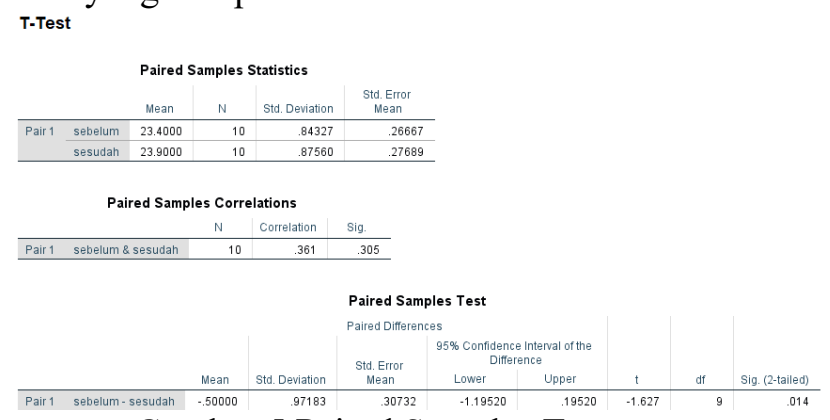

Gambar 5 Paired Samples Test

6. Keputusan : tolak $\mathrm{H}_{0}$ apabila hasil statistik terletak pada daerah penolakan $\mathrm{H}_{0}$, sebaliknya terima $\mathrm{H}_{0}$ apabila hasil statistik terletak di daerah penerimaan $\mathrm{H}_{0}$.

Pengambilan keputusan :

1. Perbandingan $\mid t$ hitung $\mid$ dan $\mid t$ tabel $\mid$ Statistik hitung $>$ statistik tabel, maka $\mathrm{H}_{0}$ ditolak. Statistik hitung $<$ statistik tabel, maka $\mathrm{H}_{0}$ diterima. 
Dalam melakukan perbandingan, maka harus menghitung $\mathrm{t}$ terlebih dahulu :

$$
\begin{gathered}
t=\frac{\mathrm{d}}{\frac{\mathrm{Sd}}{\sqrt{\mathrm{n}}}} \\
t=\frac{-50}{0,97 / \sqrt{10}} \\
=1,627
\end{gathered}
$$

\begin{tabular}{|c|c|c|c|c|c|c|}
\hline \multicolumn{7}{|c|}{$\alpha$ untuk Uji Satu } \\
\hline \multirow{3}{*}{ dk } & 0,25 & 0,10 & 0.05 & 0,025 & 0,01 & 0,005 \\
\hline & \multirow{2}{*}{\multicolumn{6}{|c|}{\begin{tabular}{|c||c|c|c|}
$\alpha$ untuk Uji Dua Pihak (cwo tail test $)$ \\
0.20 & 0.10 & 0.05 & 0.02
\end{tabular}}} \\
\hline & & & & & 0,02 & 0,01 \\
\hline 1 & 1.000 & 3,078 & 6.314 & 12,706 & 31.821 & 63,657 \\
\hline 2 & 0816 & 1886 & 2920 & 4,303 & 6.965 & 9.925 \\
\hline 3 & 0.765 & 1,638 & 2.353 & 3.182 & 4,541 & 5,841 \\
\hline 4 & 0.741 & 1.533 & 2.132 & 2,776 & 3.747 & 4.604 \\
\hline 5 & 0.727 & 1,476 & 2.015 & 2,571 & 3.365 & 4.032 \\
\hline 6 & 0,718 & 1,440 & 1,943 & 2,447 & 3,143 & 3.707 \\
\hline 7 & 0.711 & 1.415 & 1.895 & 2,365 & 2.998 & 3,499 \\
\hline 8 & 0.706 & 1.397 & 1,860 & 2,306 & 2.896 & 3.355 \\
\hline 9 & 0,703 & 1.383 & 1,833 & 2.262 & 2,821 & 3.250 \\
\hline 10 & 0,700 & 4.372 & 1,812 & 2.228 & 2.764 & 3,169 \\
\hline${ }_{12}^{11}$ & 0.697 & $\begin{array}{l}1.363 \\
1.356\end{array}$ & $\begin{array}{l}1.796 \\
1.782\end{array}$ & $\begin{array}{l}2.201 \\
2,179\end{array}$ & 2.718 & $\begin{array}{l}3.106 \\
3.055\end{array}$ \\
\hline 13 & 0.692 & $\begin{array}{l}1.350 \\
1.350\end{array}$ & 1.771 & 2,160 & $\begin{array}{l}2.081 \\
2.650\end{array}$ & $\begin{array}{l}3.055 \\
3.012\end{array}$ \\
\hline 14 & 0.691 & 1.345 & 1,761 & 2,145 & 2.624 & 2.977 \\
\hline & 0.690 & 1,341 & 1,753 & 2,131 & 2,602 & 2.947 \\
\hline 16 & 0.689 & 1.337 & 1.746 & 2,120 & 2.583 & 2,921 \\
\hline 17 & 0.688 & 1.333 & 1.740 & 2,110 & 2,567 & 2,898 \\
\hline 18 & 0,688 & 1,330 & 1.734 & 2,101 & 2.552 & 2,878 \\
\hline 19 & 0,687 & $\begin{array}{l}1.328 \\
1.325\end{array}$ & 1.729 & 2,093 & 2.539 & 2,861 \\
\hline 20 & 0,687 & $\begin{array}{l}1.325 \\
1.323\end{array}$ & 1.725 & $\begin{array}{l}2,086 \\
2080\end{array}$ & $\begin{array}{l}2,528 \\
2518\end{array}$ & $\begin{array}{l}2,845 \\
2,834\end{array}$ \\
\hline 22 & 0,686 & 1.321 & 1.717 & 2,074 & $\begin{array}{l}2,318 \\
2.508\end{array}$ & $\begin{array}{l}2.801 \\
2.819\end{array}$ \\
\hline 23 & 0.685 & 1.319 & 1.714 & 2,069 & 2.500 & 2.807 \\
\hline 24 & 0.685 & 1.318 & 1,711 & 2,064 & 2,492 & 2,797 \\
\hline & 0.684 & 1.316 & 1.708 & 2,060 & 2,485 & 2,787 \\
\hline 26 & 0.684 & 1.315 & 1,706 & 2,056 & 2,479 & 2.779 \\
\hline 27 & 0.684 & 1,314 & 1,703 & 2,052 & 2,473 & 2,771 \\
\hline 28 & 0,683 & 1.313 & 1.701 & 2,048 & 2,467 & 2,763 \\
\hline $\begin{array}{l}29 \\
30\end{array}$ & $\begin{array}{l}0.683 \\
0.683\end{array}$ & $\begin{array}{l}1.311 \\
1.310\end{array}$ & $\begin{array}{l}1,699 \\
1.697\end{array}$ & $\begin{array}{l}2,045 \\
2.042\end{array}$ & $\begin{array}{l}2,462 \\
2.457\end{array}$ & $\begin{array}{l}2.756 \\
2.750\end{array}$ \\
\hline 40 & 0.681 & 1.303 & 1.684 & 2,021 & 2,423 & 2,704 \\
\hline 60 & 0.679 & 1.296 & 1.671 & 2,000 & 2,390 & \\
\hline 120 & 0.677 & 1.289 & 1.658 & 1,980 & 2.358 & 2,617 \\
\hline & 0,674 & 1.282 & 1,645 & 1,960 & & 2.576 \\
\hline
\end{tabular}

Untuk mencari nilai $\mathrm{t}$ tabel dapat dilihat pada gambar.

Gambar 6 T. tabel

Dengan melihat tingkat signifikan $(\alpha)$ sebesar 5\% atau tingkat kepercayaan 95\%. Df (degree of freedom) atau derajat kebebasan dihitung dengan $n-1=10-1=9$. Dari hasil Analisa pertama bahwa t hitung sebesar 1,627 $>\mathrm{t}$ tabel sebesar 1,383, maka $\mathrm{H}_{0}$ ditolak. Sehingga dapat disimpulkan bahwa ada perbedaan antara menggunakan buku iqra dengan mengggunakan aplikasi pembelajaran iqra.

2. Perbandingan nilai probabilitas. Nilai probabilitas (Sig 2-tailed) > 0,05, maka $\mathrm{H}_{0}$ diterima. Nilai probabilitas (Sig 2-tailed) $<0,05$, maka $\mathrm{H}_{0}$ ditolak.

Pada tabel paired sample $t$ test, dapat dilihat hasil probabilitas (Sig 2-tailed) adalah 0,014. Dari hasil berikut dapat diambil kesimpulan bahwa nilai probabilitas (Sig 2tailed) $<0,05$, maka $\mathrm{H}_{0}$ ditolak. Maka dapat disimpulkan bahwa aplikasi berhasil secara signifikan yang dapat dilihat pada perbandingan sesudah menggunakan aplikasi lebih besar dari pada sebelum menggunakan aplikasi.

\section{SIMPULAN DAN SARAN}

\section{A. Kesimpulan}

Adapun kesimpulan yang diperoleh dari hasil analisa yang didapatkan terhadap data pengujian adalah sebagai berikut:

1. Berdasarkan pengujian blackbox testing, fungsi yang terdapat pada aplikasi pembelajaran iqra $100 \%$ valid dapat dijalankan sesuai dengan output yang diinginkan.

2. Berdasarkan hasil pengujian statitik yang dilakukan didapatkan hasil bahwa $\mathrm{H}_{0}$ ditolak dikarenakan nilai $\mathrm{t}$ hitung $1,627>$ dari $\mathrm{t}$ tabel 1,83 dan nilai probabilitas $0,014<0,05 \%$, dengan kata lain bahwa hasil sesudah menggunakan aplikasi 23,9 > hasil sebelum menggunakan aplikasi 23,4. Sehingga aplikasi ini berhasil secara signifikan.

\section{B. Saran}

Adapun saran yang dapat di peroleh dari hasil analisis adalah:

1. Pada pengembangan selanjutnya pada aplikasi pembelajaran iqra ditambahkan sampai iqra 6 .

2. Pada pengembangan selanjutnya pemilihan design marker vuforia untuk Augmented Reality harus gambar yang mempunyai persepsi terang dan gelap karena design marker vuforia di proses dalam skala grayscale dan harus mempunyai rating yang tinggi agar semakin cepat terdeteksi oleh kamera.

\section{TERIMA KASIH}

Penulis mengucapkan terima kasih kepada Tuhan YME, kepada pihak yang telah banyak memberikan bantuan dan dukungan tiada terhingga baik secara langsung maupun tidak langsung, dan Politeknik Caltex Riau.

\section{DAFTAR PUSTAKA}

[1] Kuswono Metode Iqra' K.H AS'AD HUMAM Perspektif Behavioristik. Universitas Islam Negeri Sunan Kalijaga Yogyakarta. 2016. 
[2] Suryani, Nunuk. Pengembangan Media pembelajaran Sejarah berbasis IT. Surakarta: universitas Sebelas maret Surakarta). 2016.

[3] Kim, et. al .Visualization in Engineering. Spr inger. Nugraha, dkk. 2014. Pemanfaatan Augmented Reality untuk Pembelajaran Pengenalan Alat Musik Piano. Jurnal Teknologi dan Sistem Komputer. Universitas Diponegoro. https://jtsiskom.undip.ac.id/index.php/jtsi sk om/article/view/4760/ 2015

[4] Mustaqim, I. pemanfaatan Augmented reality Sebagai Media Pembelajaran. Jurnal pendidikan Teknologi Dan Kejurua, 13(2), 174-183. 2016

[5] Christensson, P. Speech Recognition. Retrieved April 23, 2017, from terms; https://techterms.com/definition/speech $r$ ecognition. 2014

[6] Permadi, T. pemanfaatan microsoft speech application programming interface pada pembuatan aplikasi perintah suara. Jakarta : Universitas Pembangunn Nasional Veteran jakarta.2018

[7] A.S, R., \& Shalahuddin, MRekayasa Perangkat Lunak. Bandung: Penerbit Informatika. 2013

[8] Rahardjo, Setiyowati. (t.t). Uji Beda Mean Dua Sampel. http://slideplayer.info/slide/2308213/ diakses pada tanggal 1 Maret 2019

[9] Munir, Rinaldi. Pengujian Hipotesis. http://informatika.stei.itb.ac.id/ rinaldi.m unir/Probstat/20102011/Pengujian\%20Hi potesis.pdf diakses pada tanggal 1 Maret 2019

[10] Raharjo,S. Cara uji paired sample t-test www.spssindonesia.com/2016/08/carauji-paired-sample-t-test-dan.html. Diakses pada Juni 2020 